\title{
CURRENT CONCEPTS OF THE GENETICS OF THALASSEMIA
}

\author{
Donald L. Rucknagel \\ Department of Human Genetics, University of Michigan Medical School, \\ Ann Arbor, Michigan
}

Previous contributors to this symposium have defined thalassemia in clinical and hematological terms. It is obvious that thalassemia presents a broad spectrum of abnormalities and that no single hematologic parameter is pathognomic - and, indeed, does not even differentiate all types of thalassemia from environmental effects. Thus, until the primary chemical lesion is precisely defined it will be necessary to describe thalassemia by patterns of abnormalities. Organization of these patterns upon a genetic framework provides an added meaningful dimension to its characterization. Before considering the genetic aspects of thalassemia it may be well to review the genetics of abnormal hemoglobins.

Most of the inherited abnormalities of human hemoglobin are due to substitutions of single amino acid residues among the approximately 140 residues comprising either the $\alpha$ - or $\beta$-polypeptide chains of which the normal major hemoglobin component is composed. ${ }^{1,2}$ These reflect small errors in the base sequences of the deoxyribonucleic acid of which genes are composed. The genetic loci governing the structure of the $\alpha$ - and $\beta$-polypeptide chains are not closely linked." The $\mathrm{Hb} \delta$ locus, responsible for hemoglobin $\mathrm{A}_{2}\left(\mathrm{Hb} \mathrm{A}_{2}\right)$, and the $\mathrm{Hb} \beta$ structural locus are situated at most approximately 10 map units apart on the basis of genetic information available to date. ${ }^{3}$ Hemoglobins Lepore and Pylos, hemoglobinopathies manifested clinically as thalassemia ${ }^{+3,4}$ are composed of two normal $\alpha$ - and two abnormal non- $\alpha$-polypeptide chains. The latter have amino acid sequences at the $N$-terminal portion of the molecule of $\delta$-chains and $\beta$-chain sequences at the carboxyl end of the molecule. ${ }^{\top}$ On the supposition that this is due to unequal crossing over between the $\mathrm{Hb} \delta$ and $\mathrm{Hb} \beta$ loci, this allows us to orient the two loci with the $\mathrm{C}$-terminal end of the $\mathrm{Hb} \delta$ cistron close to, but not necessarily adjacent to the $\mathrm{N}$-terminal end of the $\mathrm{Hb} \beta$ cistron (FIGURE 1). Polypeptide chain synthesis apparently proceeds sequentially from the $\mathrm{N}$-terminus of the chain. ${ }^{\mathrm{T}}$ There is as yet virtually no genetic evidence to locate the $\mathrm{Hbr}$ locus for $\mathrm{Hb} F$ and this is badly needed. ${ }^{9}$

The current practice of classifying thalassemia into $\alpha$ - and $\beta$-subtypes, based upon a combination of chemical and genetic considerations, is potentially misleading if one loses sight of the types of evidence and the assumptions involved. The term $\beta$-thalassemia, coined by Ingram and

*Suppoited by USPHS Grants 5-K3-GM-15,325 and GM-09252. 
Stretton, ${ }^{10}$ is given to those thalassemia genes which "interact" with the $\mathrm{Hb} \beta$ structural mutants in individuals heterozygous for a thalassemia and an abnormal hemoglobin gene, resulting in an increase in the abnormal hemoglobin to between 70 and 100 per cent of the total hemoglobin from the 40 per cent found in the simple heterozygote's blood. Since these individuals are usually anemic, this relative increase in the amount of the abnormal hemoglobin is due to an absolute decrease in the amount of the normal hemoglobin $\beta$-polypeptide chains present. In TABLE 1 the offspring produced from matings of such double heterozygotes with normal spouses are tabulated. Of these, eight matings are gathered from the published literature (summarized in Rucknagel \& Neel $^{3}$ ) and four families, all Negro, are from my own laboratory. Of a total of 36 offspring, 16 have simple sickle cell trait, 19 have thalassemia minor, and one is questionably normal. The normality of the one potential crossover in this series was apparently in doubt." This distribution suggests that the so-called interacting type of thalassemia is allelic with or closely linked to the $\mathrm{Hb} \beta$

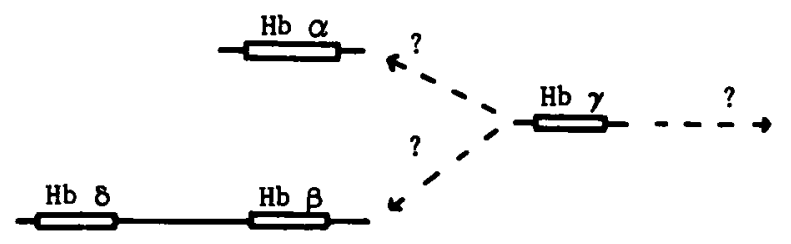

Figure 1. The linkage relationship of the hemoglobin structural loci. The position of the $\mathrm{Hb} \gamma$ locus is unknown.

structural gene. Excluding the one questionable child, if the thalassemia gene is not an allele of the $\mathrm{Hb} \beta$ structural locus, then the absence of recombinant phenotypes among 35 offspring is consistent with linkage within at most 10 map units at the 0.05 probability level. Although relatively little data have been published regarding the $\mathrm{Hb} \mathrm{A}_{2}$ levels in these families, that which is available, including the families tabulated in this report, indicates that the amount of $\mathrm{Hb} \mathrm{A}_{2}$ is increased in the thalassemia heterozygotes. Thus we have both chemical and genetic evidence to support the concept of $\beta$-thalassemia.

$\beta$-thalassemia has also been observed in combination with the minor component $\mathrm{Hb} \mathrm{A}_{2}$ (or $\mathrm{Hb} \mathrm{B}_{2}$ ). In one large three-generation family the $\beta$-thalassemia and $\mathrm{Hb}^{\delta} \mathrm{Aa}_{2}$ genes were transmitted in the coupling phase with no crossing over in eleven opportunities." Moreover, whether the thalassemia and $\mathrm{Hb} \mathrm{A}_{2}$ genes are in the coupling or repulsion phase, both components are present in twice the proportion normally encountered in an uncomplicated $A_{2} A_{2}$ ' heterozygote. ${ }^{12 .}{ }^{13}$ I shall return later to the significance of this observation. 
The concept of $\alpha$-thalassemia has evolved from chemical evidence that r-polypeptide chain synthesis is depressed in persons with hemoglobin $\mathrm{H}$ disease, also referred to as $\mathrm{Hb} \mathrm{H}$-thalassemia. These individuals, in addition to having the clinical picture of thalassemia intermedia, possess unique erythrocytic inclusion bodies ${ }^{1+}$ which are due to the instability of the $\mathrm{Hb} \mathrm{H}$ molecule. ${ }^{1.5}$ In affected persons $\mathrm{Hb}$ Bart's is also present in varying proportions..$^{16}$ In infants the amount observed is age dependent, reflecting the disappearance of $\mathrm{Hb} \mathrm{F}$ with age. 17.2! The demonstration that $\mathrm{Hb} \mathrm{H}$ is composed of four normal $\beta$-polypeptide chains $\left(\beta^{A}\right)^{23}$ and $\mathrm{Hb}$ Bart's of four $\gamma$-chains $\left(\gamma^{*}\right)^{24}$ has led to the hypothesis that the thalassemia gene (s) involved in $\mathrm{Hb} \mathrm{H}$-disease results in a relative deficiency of $\alpha$-chains, the excess $\beta_{2}^{A}$ - and $\gamma^{F}$-dimers polymerizing into the abnormal homogeneous tetramers. The thalassemia trait associated with $\mathrm{Hb} \mathrm{H}$-disease as well as the disease itself is characterized by normal or subnormal amounts of $\mathrm{Hb} \mathrm{\textrm {A } _ { 2 } . 2 5 \cdot 2 7}$

TABLE 1

Genotype Distribution from Offspring of MarRiages of Sickle Cell-Thalassemia and Normal Parents

\begin{tabular}{|c|c|c|c|c|c|c|}
\hline Authors* & $\begin{array}{l}\text { Ethnic } \\
\text { origin }\end{array}$ & $\begin{array}{c}\text { Sickle } \\
\text { cell- } \\
\text { thalassemia }\end{array}$ & Normal & $\begin{array}{l}\text { Thal. } \\
\text { minor }\end{array}$ & $\begin{array}{l}\text { Sickle } \\
\text { cell } \\
\text { trait }\end{array}$ & $\Sigma$ \\
\hline \multirow[b]{2}{*}{$\begin{array}{l}\text { Silvestroni \& Bianco, } 1952 \dagger \\
\text { Powell, Rodarte \& Neel, } 1950 \dagger \\
\text { Aksoy \& Lehmann, 1957 } \\
\text { Cohen, Zuelzer, Neel \& } \\
\quad \text { Robinson, } 1959\end{array}$} & \multirow[b]{2}{*}{$\begin{array}{c}\text { Italian } \\
\text { Italian } \\
\text { Turkish } \\
\text { Negro }\end{array}$} & \multicolumn{5}{|c|}{ "Noninteracting" } \\
\hline & & $\begin{array}{l}1 \\
0 \\
0 \\
1 \\
2 \\
\end{array}$ & $\begin{array}{l}0 \\
0 \\
1 \\
3 \\
\overline{4}\end{array}$ & $\begin{array}{l}0 \\
2 \\
1 \\
1 \\
4\end{array}$ & $\begin{array}{l}0 \\
0 \\
2 \\
3 \\
\overline{5}\end{array}$ & $\begin{array}{r}1 \\
2 \\
4 \\
8 \\
15 \\
\end{array}$ \\
\hline & & \multicolumn{5}{|c|}{ “Interacting" } \\
\hline $\begin{array}{l}\text { Neel, Itano \& Lawrence, } 1953 \\
\text { Ceppellini, } 1959\end{array}$ & $\begin{array}{c}\text { Greek } \\
\text { Negro } \\
\text { Negro } \\
\text { Italian } \\
\text { Afro-Italian } \\
\text { Negro } \\
\text { Negro } \\
\text { Italian } \\
\end{array}$ & $\begin{array}{l}0 \\
0 \\
0 \\
0 \\
0 \\
0 \\
0 \\
0 \\
\end{array}$ & $\begin{array}{l}0 \\
0 \\
0 \\
0 \\
0 \\
0 \\
1(?) \\
0 \\
\end{array}$ & $\begin{array}{l}0 \\
3 \\
1 \\
2 \\
0 \\
2 \\
3 \\
2 \\
\end{array}$ & $\begin{array}{l}1 \\
4 \\
2 \\
2 \\
1 \\
1 \\
1 \\
1 \\
1\end{array}$ & $\begin{array}{l}1 \\
7 \\
3 \\
3 \\
1 \\
3 \\
5 \\
4 \\
\end{array}$ \\
\hline Rucknagel, This Annals & $\begin{array}{l}\text { Negro } \\
\text { Negro } \\
\text { Negro } \\
\text { Negro }\end{array}$ & $\begin{array}{l}0 \\
0 \\
0 \\
0 \\
\overline{0}\end{array}$ & \begin{tabular}{l|}
0 \\
0 \\
0 \\
0 \\
$1(?)$
\end{tabular} & $\begin{array}{r}3 \\
2 \\
1 \\
0 \\
19\end{array}$ & $\begin{array}{c}0 \\
2 \\
0 \\
1 \\
16\end{array}$ & $\begin{array}{r}3 \\
4 \\
1 \\
1 \\
36\end{array}$ \\
\hline
\end{tabular}

* See Reference 2.

† Hemoglobin electrophoresis not performed. 
TABLE 2

Phenotype of Parents and Offspring of Families Possessing $\mathrm{Hb}_{\beta}^{\mathrm{E}}$ AND $\alpha$-Thalassemia Genes 36,48

\begin{tabular}{|c|c|c|c|c|c|c|c|c|c|}
\hline & \multirow{2}{*}{$\begin{array}{c}\mathrm{Hb} \\
\text { Conc. } \\
\mathrm{gm} \%\end{array}$} & \multirow{2}{*}{$\begin{array}{l}\text { Morph. } \\
\text { Abn. }\end{array}$} & \multicolumn{4}{|c|}{$\mathrm{Hb}$ Electrophoresis } & \multirow{2}{*}{ - $\begin{array}{c}\text { Number } \\
\text { observed }\end{array}$} & \multirow{2}{*}{$\begin{array}{c}\text { Expected } \\
\text { ratio }\end{array}$} & \multirow{2}{*}{ Designation } \\
\hline & & & $\mathbf{E}$ & H & Bart's & $\mathrm{A}_{2}$ & & & \\
\hline \multirow[t]{2}{*}{ Parents } & $10-14$ & + & - & $\cdot$ & - & $1.8-3.0$ & 4 & & $\alpha$-thalassemia trait \\
\hline & $12-13$ & + & 25 & - & - & - & 3 & & $\mathrm{Hb}_{\beta}^{\mathrm{E}}$ trait- $\alpha$-thalassemia \\
\hline Propositi & $6-9$ & ++++ & $12-16$ & - & $8-17$ & - & 6 & 1 & $\begin{array}{l}\mathrm{Hb}_{\beta}^{\mathrm{E}} \text {-trait- } \alpha \text {-thalassemia } \\
\text { disease }\end{array}$ \\
\hline \multirow[t]{5}{*}{$\begin{array}{l}\text { Siblings of } \\
\text { Propositi }\end{array}$} & $8-10$ & ++++ & - & 15 & \pm & $1.3-2.6$ & 2 & 1 & $\begin{array}{c}\alpha \text {-thalassemia disease } \\
\text { (Hb H disease) }\end{array}$ \\
\hline & 12 & + & 28 & - & - & - & 1 & 2 & $\begin{array}{l}\mathbf{H b}_{\beta}^{\mathrm{E}} \text { trait- } \alpha \text {-thalassemia } \\
\text { trait }\end{array}$ \\
\hline & $10-14$ & + & - & - & - & $2.1-2.7$ & 2 & 2 & $\alpha$-thalassemia trait \\
\hline & 14 & $\mathrm{~N}$ & - & - & - & $1.4-2.1$ & 2 & 1 & Normal \\
\hline & 14 & + & $>\mathbf{3 0}$ & - & - & - & 0 & 1 & $\mathrm{Hb}_{\beta}^{\mathrm{E}}$ trait \\
\hline
\end{tabular}

Chemical evidence provides a striking analogy between the effect of the $\alpha$ - and $\beta$-thalassemia genes on the $\mathrm{Hb} \alpha$ and $\mathrm{Hb} \beta$ structural mutants, respectively. One individual with $\mathrm{Hb}^{1} \alpha$ and two with $\mathrm{Hb}^{9} \alpha$ in addition to an $\alpha$-thalassemia gene have been described ${ }^{28-30}$ in whom the amount of abnormal hemoglobin present is of the order of 70 per cent. In both of the latter cases $\mathrm{Hb} \mathrm{H}$ or Bart's $\mathrm{Hb}$ were present as well as a diminished amount of $\mathrm{Hb} \mathrm{A}_{2}$, serving to identify the thalassemia clearly as of the $\alpha$-type. Despite this chemical evidence there is still no direct genetic evidence for linkage of the $\alpha$-thalassemia and $\mathrm{Hb} \alpha$ loci. This must come from studies of the offspring of matings of appropriate double heterozygotes with normal spouses.

The genetics of hemoglobin H-disease are more complex than that of the $\beta$-thalassemia syndromes. In the first family reported with $\mathrm{Hb} \mathrm{H}$ disease, one parent of the affected individuals had hematologic evidence of mild thalassemia, the other parent was apparently normal. This led to postulation that the gene for $\mathrm{Hb} \mathrm{H}$ was expressed only upon a background of thalassemia. ${ }^{31,32}$ To date 22 families have been described in which offspring have $\mathrm{Hb} \mathrm{H}$-disease and in which both parents have been studied and found not to have $\mathrm{Hb} \mathrm{H}$-disease. In eleven of these families both parents show some hematologic evidence of thalassemia, ${ }^{25.27 .33-36}$ in ten only one parent had any evidence, ${ }^{13.35 .38 \cdot+4}$ and in one family both parents ap- 
peared normal. ${ }^{45}$ The presence of minimal evidence for thalassemia in both parents of so many persons with $\mathrm{Hb} \mathrm{H}$-disease suggests that affected individuals have two thalassemia genes. ${ }^{16.42-4 t}$ It also suggests that in those families in which only one parent is affected, the trait is completely recessive in the phenotypically normal parent. This situation is not unlike that confronting Neel in his contemplation of the genetics of sickle cell anemia in $1947 .{ }^{40}$

Are two different $\alpha$-thalassemia genes involved, or does this represent variable expression of a single gene? If $\mathrm{Hb} \mathrm{H}$-disease is due to two allelic $\alpha$-thalassemic genes, one of which is associated with demonstrable morphologic abnormalities and the other completely recessive, and if these are present in a population at frequencies $q$ and $r$, respectively, and if the frequency of the remaining "wild type" alleles is taken as $p$, the ratio of matings resulting in $\mathrm{Hb} \mathrm{H}$-disease offspring in which both parents, one parent, or neither parent has evidence of $\alpha$-thalassemia is $4 \mathrm{p}^{2} \mathrm{q}^{2}: 8 \mathrm{p}^{2} \mathrm{qr}: 4 \mathrm{p}^{2} \mathrm{r}^{2}$, respectively. This reduces to $\mathrm{q}^{2}: 2 \mathrm{qr}: \mathrm{r}^{2}$. Thus if the "visible" allele is twice as common as the recessive one $(q=2 r)$, the ratio of respective parents would be $4: 4: 1$, not unlike that reported to date. The distribution of such matings cited from the literature cannot be taken too seriously, however, because of the diversity of ethnic groups from which the families were drawn and because of the biases inherent in case reporting. Nevertheless, inequality of the frequency of two alleles will explain the above mentioned discrepancies in family data. On the other hand, in five families $\mathrm{Hb} \mathrm{H}$ disease has been reported in offspring and one parent; the other parent was shown to be normal, ${ }^{211}: 18.33,45.47$ suggesting that it is due to a dominant gene. Taken at face value, these families would seem to contradict the family data referred to previously. Since $\mathrm{Hb} \mathrm{H}$-disease is not uncommon in southeast Asia, however, the assumption that the phenotypically normal parent is indeed genotypically normal may be unwarranted. Moreover, in the families described in which $\mathrm{Hb} \mathrm{H}$-disease is present in parents and offspring, consanguinity apparently has not been considered.

Further evidence that $\mathrm{Hb} \mathrm{H}$-disease is due to two recessive or nearly recessive genes is provided by some studies of informative families presented by Virginia Minnich, myself, and our colleagues in Thailand ${ }^{36.48}$ and summarized in TABLE 2. Five families were ascertained through a child who had severe hypochromic, microcytic hemolytic anemia. These children had approximately seven gm. per cent hemoglobin, splenomegaly, and the hemoglobin electrophoretic pattern consisted of approximately 15 per cent $\mathrm{Hb} \mathrm{E}, 10$ per cent Bart's $\mathrm{Hb}$, and the remainder $\mathrm{Hb} \mathrm{A}$. The $\mathrm{Hb} \mathrm{E}$ component was fingerprinted and found not to be largely $\mathrm{Hb} \mathrm{A}_{2}$. Among 13 children there were six with this phenotype. Among the five families there were also two children with $\mathrm{Hb} \mathrm{H}$ disease, having approximately 15 per cent $\mathrm{Hb} \mathrm{H}$ and detectable amounts of Hb Bart's. One child's 


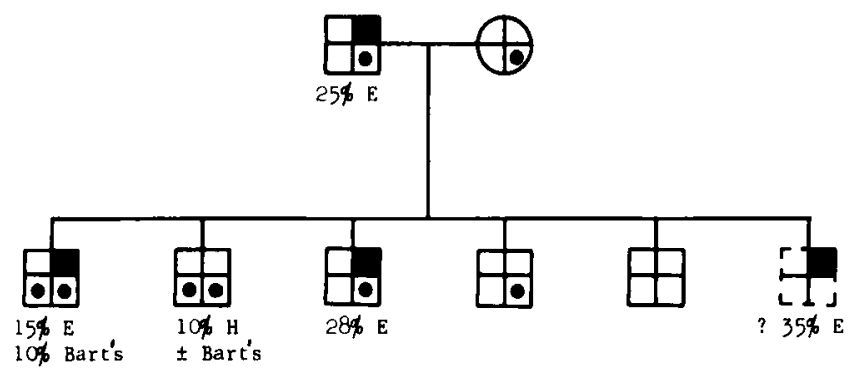

Figure 2. Schematic interpretation of the family data presented in TABLE 2 in which one parent has $\mathrm{Hb} \beta \mathrm{E}$ trait- $\alpha$-thalassemia trait and the other $\alpha$-thalassemia trait. The black quadrants represent a $\mathrm{Hb} \beta^{\mathrm{E}}$ gene, the dot an $\alpha$-thalassemia. White quadrants represent the normal allele. Offspring with simple $\mathrm{Hb} \mathrm{E}$ trait were expected but not observed.

blood contained 28 per cent $\mathrm{Hb} \mathrm{E}$. Two children were normal and two had minimal erythrocytic morphologic evidence of thalassemia minor. One parent of each family possessed $\mathrm{Hb}^{\mathrm{E}} \beta$, but in the three parents in which it was measured the amount of $\mathrm{Hb} \mathrm{E}$ varied between only 21 and 25 per cent. The other hematologic abnormalities in this parent were consistent with simple $\mathrm{Hb} \mathrm{E}$ trait. In the blood of the other parent in four of the families there was minimal morphologic evidence for thalassemia. The amount of $\mathrm{Hb} \mathrm{A}$ present was normal in two and low in two. The interpretation of these families, shown schematically in the pedigree of FIGURE 2 , is that the parents (and one child) with $\mathrm{Hb} \mathrm{E}$ values below 30 per cent, at the lower limit of the range observed in heterozygotes, are heterozygous for an $\alpha$-thalassemia gene as well as for $\mathrm{Hb}^{\mathrm{E}} \beta$. The other parent also has

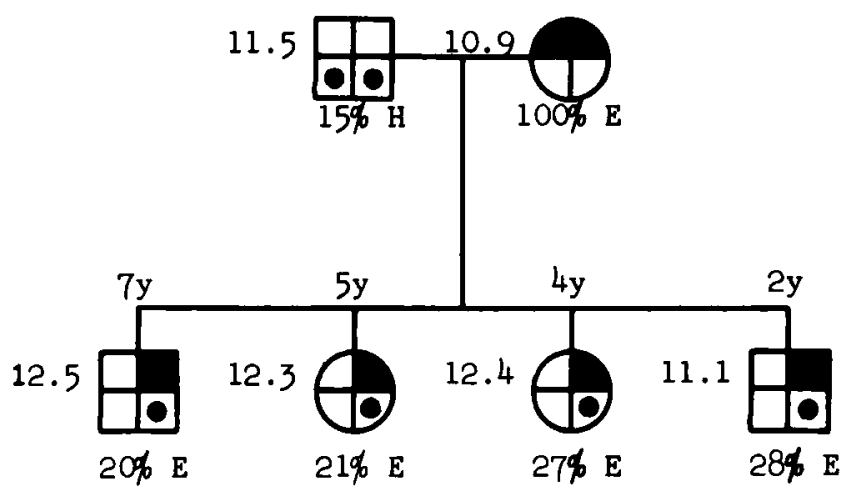

FIGURE 3. Interpretation of a family in which the mother has homozygous $\mathrm{Hb} \mathrm{E}$ disease and the father $\mathrm{Hb} \mathrm{H}$-disease, intel'pretated as due to two $\alpha$-thalassemia genes. The figures to the left of each symbol refer to the total hemoglobin level, those above to the pel'son's age. Symbols as in FIGURE 2. 
an $\alpha$-thalassemia gene. The children with even less $\mathrm{Hb} \mathrm{E}$ and, in addition, $\mathrm{Hb}$ Bart's have two thalassemia genes in addition to $\mathrm{Hb}^{\mathrm{E}} \beta$. The children with $\mathrm{Hb} \mathrm{H}$-disease possess two $\alpha$-thalassemia genes. If this interpretation is correct, the $\alpha$-thalassemia locus is not closely linked to the $\mathrm{Hb} \beta$ structural locus since the $\mathrm{Hb}$ E-containing parent could transmit two, one, or none of the mutant genes. We have designated the children having $\mathrm{Hb}$ 's $\mathrm{E}$ and Bart's as $\mathrm{Hb}^{\mathrm{E}} \beta$ trait- $\alpha$-thalassemia disease, and the parent containing $\mathrm{Hb} \mathrm{E}$ as $\mathrm{Hb}^{\mathrm{E}} \beta$ trait- $\alpha$-thalassemia trait (TABLE 2). We should have observed some children with simple $\mathrm{Hb} \mathrm{E}$ trait having more than 30 per cent $\mathrm{Hb} \mathrm{E}$, but in this small series none were found.

Another family in which one parent had $\mathrm{Hb} \mathrm{H}$-disease and the other homozygous $\mathrm{Hb} \mathrm{E}$ disease (FIGURE 3 ) was also consistent with this interpretation. All four children produced from this union had $\mathrm{Hb} \mathrm{E}$ trait with $\mathrm{Hb} \mathrm{E}$ concentrations at the low end of the range, two having 22 per cent and two having 28 per cent. We have suggested that the parent with $\mathrm{Hb} \mathrm{H}$ had two different $\alpha$-thalassemia genes $\left(t_{1} t_{2}\right)$ which suppress the amount of $\mathrm{Hb} \mathrm{E}$ present in the offspring to different degrees. Extension of these studies may provide the most direct evidence for the existence of two $\alpha$-thalassemia alleles.

The effect of the proposed $\alpha$-thalassemia genes in these families is shown in FIGURE 4 . In these histograms the blood of normal individuals is shown as possessing seven $\mathrm{gm}$. per cent each of $\alpha$ - and $\beta$-polypeptide chains, respectively. In $\mathrm{Hb} \mathrm{H}$-disease ( $\alpha$-thalassemia disease) characterized by 10.4 gm. per cent hemoglobin and 15 per cent $\mathrm{Hb} \mathrm{H}, \alpha$-chains are decreased, but the total amount of $\beta$-chains is also decreased to six $\mathrm{gm}$. per cent. In the $\mathrm{Hb}$ E-trait individual the amount of non- $\alpha$-chains is distributed between $\beta^{\mathrm{E}}$ - and $\beta^{A}$-chains. In $\mathrm{Hb} \mathrm{E}$ trait- $\alpha$-thalassemia trait fewer $\beta^{\mathrm{E}}$-chains are present but the amount of $\beta^{A}$ - is increased. A similar phenomenon has been observed in the so-called non-interacting sickle cell-thalassemia family described by Cohen et al." in which the $\mathrm{Hb} \mathrm{A}_{2}$ was not increased but only 22 to 27 per cent of the hemoglobin was $\mathrm{Hb} \mathrm{S}$. In critical families these genes also segregate independently (TABLE 1). In $\mathrm{Hb}^{\mathrm{E}} \beta$ trait- $\alpha$-thalassemia $\alpha$ - and $\beta^{A}$-chains are depressed but the $\beta^{\mathrm{E}}$-chain content is disproportionately lower. Despite the increase of $\gamma$-chains as Hb Bart's, the total amount of non- $\alpha$-chains is still diminished. Thus the $\alpha$-thalassemia genes exert an effect on the non-linked $\mathrm{Hb} \beta$ locus. This is not unlike the action of the $\beta$-thalassemia gene of the $\mathrm{Hb}^{\mathrm{A}: 2}$ and $\mathrm{Hb}^{\mathrm{A}^{12}}$ alleles in the trans as well as in the cis configuration. By analogy, one would anticipate that the $\beta$-thalassemia genes when combined with the $\alpha$-chain structural mutants will depress the amount of abnormal hemoglobin present.

There is a tendency now to equate these effects with diminished rate of hemoglobin synthesis. If erythrocyte lifespan is very short in these anemic individuals, net hemoglobin synthesis may be greatly increased. Likewise, 
if the hemoglobin components are not homogeneously distributed among erythrocytes - and there is some evidence suggesting that $\mathrm{Hb} \mathrm{F}$ is not ${ }^{50}-$ and if erythrocyte lifespan is not uniform, net relative rate of synthesis of a give abnormal hemoglobin may be high although in whole blood it may constitute a smaller proportion of the hemoglobin present.

Another intriguing question is that of the relationship between Bart's $\mathrm{Hb}$ in infancy and $\alpha$-thalassemia. Using predominately paper electrophoresis

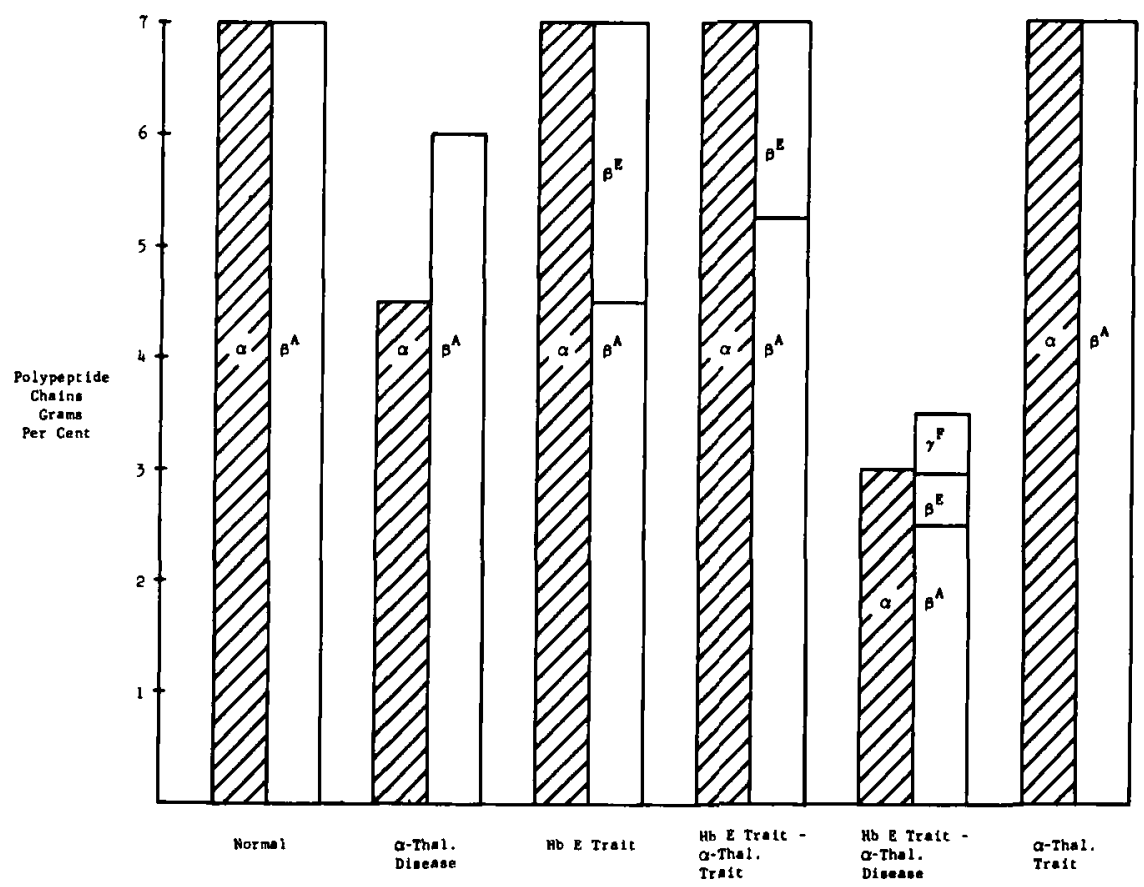

FigURE 4. The effect of $\alpha$-thalassemia genes on the absolute amount of hemoglobin circulating as $\alpha-, \beta$, and $\gamma$-polypeptide chains, respectively. The contribution of normal fetal hemoglobin has been neglected for simplicity.

Tuchinda et al. ${ }^{17}$ and Lie-Injo ${ }^{1 \times}$ have found small amounts of $\mathrm{Hb}$ Bart's in about five per cent of cord bloods in southeast Asia. In this country Minnich et al. ${ }^{21}$ found Bart's $\mathrm{Hb}$ in approximately seven per cent of cord bloods of Negroes using starch block electrophoresis. Weatherall has found 5 to 10 per cent of it in approximately two per cent of a series of 1000 cord bloods of Negroes and trace amounts in nearly all cord bloods." authors have produced evidence for thalassemia among parents and other relatives of the infants with the larger amounts. $\mathrm{Hb}$ Bart's has also been found in 10 per cent of newborn infants in Nigeria." Yet, outside of Southeast Asia $\mathrm{Hb} \mathrm{H}$-disease is rare. Weatherall has quite properly postulated 
that two genes are necessary for $\mathrm{Hb} \mathrm{H}$-disease and only one of these is prevalent in the American Negro. ${ }^{22}$ Lie-Injo has described in stillborm fetuses erythroblastosis accompanied by large amounts of $\mathrm{Hb}$ Bart's and has suggested that this is due to homozygosity for $\alpha$-thalassemia genes. ${ }^{51}$ This raises the possibility that some but not necessarily all of the homozygotes for the gene responsible for the Bart's Hb of the newborn Negro are not seen because of in utero lethality. Are the two postulated genes responsible for $\mathrm{Hb} \mathrm{H}$ allelic or not? The only clear test of this at present is a study of offspring of $\mathrm{Hb} \mathrm{H}$-disease persons married to normal spouses. Because of the probability that the heterozygous state of the $\alpha$-thalassemia gene is undetectable in many instances and because of the apparently high probability in Southeast Asia that phenotypically normal persons may be in fact $\alpha$-thalassemia heterozygotes, this approach is not likely to be a critical one. Indeed, differentiating multiple allelic inheritance from genes distributed among multiple loci, when the genotypes cannot be precisely identified, constitutes one of the more difficult problems in human genetics. Numerous atypical patterns of abnormalities have been described and classed as $\beta$-thalassemia. Experience with similar modifier genes in other organisms suggests that we can expect all possible variations among thalassemia genes which ultimately will prove to be linked with the $\mathrm{Hb} \beta$ locus. Caution might therefore be used before considering thalassemia without increased amounts of $\mathrm{Hb} \mathrm{A}_{2}$ as $\alpha$-thalassemia. To date, the only reliable criterion for $\alpha$-thalassemia is the presence of Bart's $\mathrm{Hb}$ and perhaps interaction with structural mutants.

From the facts at hand can we come to any conclusions regarding the basic nature of thalassemia? Before attempting to do so a brief summary of current concepts of 'cellular control of protein synthesis is in order. Based upon biochemical studies and genetic fine structure mapping in bacteria, Jacob and Monod ${ }^{25}$ have postulated the existence of "operator" genes which appear to control the expression of blocks of juxtaposed structural genes. The operator gene exerts its effect upon structural genes in the same chromosome or DNA strand, i.e., in the cis position. In a manner not yet understood it controls either the rate at which the information embodied in the structural genes is transcribed into a ribonucleotide referred to as messenger ribose nucleic acid, or it governs the rate at which the structural proteins are synthesized on the messenger RNA template. The operator is in turn repressed by a molecule, currently believed to be a protein, which is under the control of another genetic locus which may not even be linked to the operon, as the block of operator plus structural genes is designated. As indicated earlier, there is ample evidence to indicate that the $\mathrm{Hb} \delta$ and $\mathrm{Hb} \beta$ structural loci are closely linked. In an inherited entity referred to as the high fetal hemoglobin gene heterozygotes retain approximately 30 per cent of $\mathrm{Hb} \mathrm{F}$ into adulthood without any other 
hematologic abnormality. A homozygote for this gene lacks both hemoglobins $\mathrm{A}_{2}$ and $\mathrm{A}^{53}$ This observation has led Neel" and Motulsky ${ }^{54}$ to suggest that the high $F$ gene ( $O F$ in FIGURE 5 ) may be equated with the operator gene of the microbial systems, in which a mutation has resulted in a failure to synthesize both $\delta$ - and $\beta$-chains. Deletion of the $\mathrm{Hb} \beta$ and $\mathrm{Hb} \delta$ loci is still an equally likely possibility, however.

Itano $0^{35}$ and Ingram and Stretton ${ }^{10}$ have postulated that thalassemia may be the result of a "silent substitution" of the hemoglobin polypeptide chain in which an amino acid is substituted by one of like charge and thus not detected electrophoretically. Although the contrary evidence is not overwhelming, enough exists to force H. A. Itano (see p. 816) to speculate that the diminished rate of hemoglobin synthesis in thalassemia is due to degeneracy ${ }^{5 i}$ of the $\alpha$ - or $\beta$-chain structural code. Ingram has likewise advanced an alternate hypothesis (see p. 485 ). 1 have summarized evidence indicating that $\alpha$-thalassemia is not linked to the $\mathrm{Hb} \beta$ structural locus

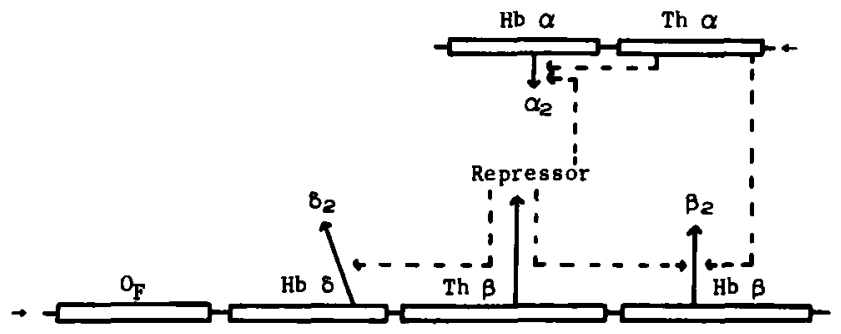

FIGURE 5. Hypothetical linkage relationships between the thalassemia and hemoglobin structural loci. The small horizontal arrows indicate polarity of the respective chromosomes collesponding to the direction of polypeptide chain synthesis. The dotted arrows represent regulation of the indicated chain synthesis by a hypothetical repressor substance (or by lack of an inducer).

despite exerting an apparently direct effect upon it. This is in conflict with the hypothesis of Nance ${ }^{57}$ which attributes $\alpha$-thalassemia to a fusion gene formed by unequal crossing over involving the $\mathrm{Hb} \beta, \mathrm{Hb} \delta$, and the presumably closely linked $\mathrm{Hb} \gamma$ loci. Since the total hemoglobin level in $\beta$. thalassemia is depressed only approximately 15 per cent, but the total amount of $\mathrm{Hb} \mathrm{A}_{2}$ is doubled, the increase in $\mathrm{Hb} \mathrm{A}_{2}$ appears absolute rather than relative to the decrease in $\mathrm{Hb} A$. Moreover, $\beta$-thalassemia appears to enhance the expression of both the $\mathrm{Hb} \delta^{\mathrm{Al}^{2}}$ and $\mathrm{Hb} \delta^{\mathrm{A} \cdot 2}$ genes in individuals heterozygous at both loci. Thus it influences genes in the trans position or repulsion phase as well as the cis. Thalassemia, therefore, appears to function as the repressor gene of Jacob and Monod, despite the fact that $\beta$-thalassemia is closely linked if not allelic with the $\mathrm{Hb} \beta$ or $\mathrm{Hb} \delta$ structural loci. In FIGURE 4 the author has located the $\beta$-thalassemia locus between 
the $\mathrm{Hb} \delta$ and $\mathrm{Hb} \beta$ structural loci, primarily because the hematologic manifestations of $\mathrm{Hb}$ Lepore can be explained as a deletion of that locus. This utilizes clinical evidence to answer a genetic question, however, and until linkage information appears, the relationship between the structural loci and thalassemia is conjectural. This still tells us nothing about the nature of thalassemia.

Robin M. Bannerman reviews the evidence that porphyrin metabolism is apparently disturbed in thalassemia (p. 503). Paul A. Marks (p. 513) and V. M. Ingram (p. 485) present evidence that the ribosomes of thalassemic erythroblasts do not function normally. Can all of these aspects be integrated with the genetic observations? Are these lesions primary or merely secondary manifestations of "sick cells"? The fact that $\beta$-thalassemia genes can be more readily identified than $\alpha$-thalassemia genes with the techniques at our disposal may be a hint that the two entities produce hypochromic anemia and the electrophoretic interactions by entirely different mechanisms. It seems to me that we will not be able to determine whether a given chemical abnormality represents the primary biochemical effect of the thalassemia gene until we can correlate these abnormalities with the variability of thalassemia within this genetic framework.

\section{REFERENCES}

1. Baglioni, C. 1963. Correlations between genetics and chemistry of human hemoglobin. In Progress in Molecular Genetics. : 405-475. H. Taylor, Ed. Academic Press. New York, N. Y.

2. Rucknagel, D. L. \& J. V. Neel. 1961. The hemoglobinopathies. In Progress in Medical Genetics, 1: 158-260. A. G. Steinberg, Ed. Grune \& Stratton. New York, N.Y.

3. Boyer, S. H., D. L. Rucknagel, D. J. Weatherall \& E. J. WatsonWILliams. 1963. Further evidence for linkage between the $\beta$ and $\delta$ loci governing human hemoglobin and the population dynamics of linked genes. Am. J. Hum. Genet. 15: 438-448.

4. Gerald, P. S. \& L. K. Diamond. 1958. A new hereditary hemoglobinopathy (the Lepore trait) and its interaction with thalassemia trait. Blood 13: 835-844.

5. Neeb, H., J. L. Bieboer, J. H. P. Jonxis, J. A. K. Sijpesteijn \& C. J. MULLER. 1961. Homozygous Lepole haemoglobin disease appearing as thalassemia major in two Papuan siblings. Trop. Geograph. Med. 13: 207-215.

6. Fessas, P., G. Stamatoyannopoulos \& A. Karaklis. 1962. Hemoglobin "Pylos": study of a hemoglobinopathy resembling thalassemia in the heterozygous, homozygous and double hetelozygous state. Blood 19: 1-22.

7. BAGLioni, C. 1962. The fusion of two peptide chains in hemoglobin Lepore and its interaction as a genetic deletion. Proc. Nat. Acad. Sci. U.S. 48: $1880-1886$.

8. Naughton, M. A. \& H. M. Dintzis. 1962. Sequential biosynthesis of the peptide chains of hemoglobin. Proc. Nat. Acad. Sci. U. S. 48: 1822-1830.

9. NeEL, J. V. 1961. The hemoglobin genes: a remarkable example of the clustering of related genetic functions on a single mammalian chromosome. Blood 18: 769-777.

10. Ingram, V. M. \& A. O. W. Stretton. 1959. Genetic basis of the thalassemia diseases. Natule (London) 184: 1903-1909. 
11. Ceppellini, R. 1959. In discussion of Hunt, J. A. and Ingram, V. M., "The genetical control of protein structure: thee abnormal human haemoglobins." In Biochemistry of Human Genetics. : 133-138. G. E. W. Wolstenholme \& C. M. O'Connor', Eds. Churchill. London, England.

12. Huisman, T. H. J., K. Punt \& J. D. G. SchaAd. 1961. Thalassemia minor associated with hemoglobin- $\mathrm{B}_{2}$ heterozygosity. A family report. Blood 17: $747-756$.

13. Ceppellini, R. 1959. L'emoglobina normale lenta $A_{2}$ : suoi lapporti con una nuova frazione emoglobinica lenta, $B_{2}$, e sua importanza per il riconoscimento di varianti talassemiche che compaiono nelle famiglie di portatori di thalassemia media e di emoglobinopatia H. Acta Genet. Med. (Roma) 8: (Suppl. 2): 47-68.

14. Minnich, V., S. Na-Nakorn, S. Chongchareonsuk \& S. Kochaseni. 1954. Mediterranean anemia, a study of 32 cases in Thailand. Blood 9: 1-23.

15. Rigas, D. A. \& R. D. KoleR. 1961. Decreased erythrocyte survival in hemoglobin $\mathrm{H}$ disease as a result of the abnormal properties of hemoglobin $\mathrm{H}$ : the benefit of splenectomy. Blood 18: 1-17.

16. Huehns, E. R., E. R. Flyn , E. A. Butler \& E. N. Shooter. 1960. The occurrence of haemoglobin "Bart's" in conjunction with haemoglobin $\mathrm{H}$. Brit. J. Haemat. 6 : 388-394.

17. Tuchinda, S., C. Vareenil, P. Bhanchit \& V. Minnich. 1959. "Fast" hemoglobin component found in umbilical-cord blood of Thai babies. Pediatrics 24 : 43-49.

18. LiE-INJO, L. E. 1959. Haemoglobin of new-born infants in Indonesia. Nature (London) 183: 1125.

19. VeLLA, F. 1959. Heterogeneity of human foetal haemoglobin. Incidence of foetal variants in Singapore. Nature (London) 184: 272.

20. Hendrickse, R. G., A. E. Boyo, P. A. Fitzgerald \& S. R. Kuti. 1960. Studies on the haemoglobin of newborn Nigerians. Brit. Med. J. 1: 611-614.

21. Minnich, V., J. K. Cordon Nier, W. J. Williams \& C. V. Moore. 1962. Alpha, beta, gamma hemoglobin polypeptide chains during the neonatal period with description of a fetal form of hemoglobin Da St. Louis. Blood 19: 137-167.

22. Weatheral, D. J. 1963. Abnormal haemoglobins in the neonatal period and their relationship to thalassaemia. Brit. J. Haemat. 9: 265-277.

23. Jones, R. T., W. A. Schroeter, J. E. Balog \& J. R. Vinograd. 1959. Gross structure of hemoglobin H. J. Am. Chem. Soc. 81: 3161 .

24. Hunt, J. A. \& H. LehmanN. 1959. Haemoglobin "Bart's"; a foetal haemoglobin without $\alpha$-chains. Nature (London) 184: 872-873.

25. Hedenberg, F., U. Muller-Eberhard, S. Suölin \& L. Wranne. 1958. Haemoglobin $\mathrm{H}$ and inclusion-body anemia in a Swedish family. Acta Paediat. (Stockholm) 47: 652-665.

26. Dittman, W. A., A. Haut, M. M. Wintrobe \& G. E. Cartwright. 1960. Hemoglobin $H$ associated with an uncommon variant of thalassemia trait. Blood 16 : 975-983.

27. Quattrin, N., V. Ventruto, E. Dini \& L. Aloia. 1961. Sull' associazione emoglobina Bart's e microcitanemia. Prima osservazione Italiana. Minerva Med. 52 : 3189-3197.

28. Atwater, J., I. R. Schwartz, A. J. Erslev, T. L. Montgomery \& L. M. Tocantins. 1960. Sickling of elythrocytes in a patient with thalassemiahemoglobin-I disease. New Eng. J. Med. 263: 1215-1223.

29. Vella, F., R. H. C. Wells, J. A. M. Ager \& H. LehmanN. 1958. A haemoglobinopathy involving haemoglobin $\mathrm{H}$ and a new (Q) haemoglobin. Brit. Med. J. 1 : 752-755.

30. Dormandy, K. M., S. P. Lock \& H. Lehman N. 1961. Haemoglobin Q-alphathalassaemia. Brit. Med. J. 1: 1582-1585.

31. Rigas, D. A., R. D. Koler \& E. E. Osgood. 1956. Hemoglobin H. J. Lab. Clin. Med. 47 : 51-64. 
32. Motulsky, A. 1956. Genetic and hematological significance of hemoglobin H. Nature (London) 178: 1055-1056.

33. Fessas, P. \& A. Papaspyrov. 1957. New "fast" hemoglobin associated with thalassemia. Science 126: 1119.

34. Lie-Injo, L. E., S. H. Poey, L. K. Kho \& P. M. Endenburg. 1957. Chronic hypochromic microcytic anaemia associated with hemoglobin $H$. Acta Haemat. 18 : 156-167.

35. Ager, J. A. M. \& H. Lehmann. 1958. Observations on some "fast" haemoglobins: K, J, N, and "Bart's." Brit. Med. J. 1: 929-931.

36. Tuchinda, S., D. L. Rucknagel, V. Minnich, U. Boonyaprakob, K. Balankura \& V. Suvatee. 1964. The coexistence of the genes for hemoglobin $E$ and $a$-thalassemia in Thais, with resultant suppression of hemoglobin E synthesis. Am. J. Hum. Genet. In press.

37. Went, L. N. \& J. E. MAC IVer. 1961. Thalassemia in the West Indies. Blood 17 : 166-181.

38. Gouttas, A., P. Fessas, H. Tservrenis \& E. Xefteri. 1955. Description d'une nouvelle variété d'anémie hémolytique congenitale (etude hématologique, électrophorétique et génétique). Le Sang. (Paris) 26: 911920.

39. Minnich, V., S. Na-Nakorn, S. Tuchinda, P. Wasi \& C. V. Moore. 1956. Inclusion body anemia in Thailand (hemoglobin-H-thalassemia disease). Proc. 6th Cong. Internat. Soc. Hemat., (Rome). : 743.

40. WolfF, J. A., R. H. Michaels \& F. H. VoN Hoff. 1958. Hemoglobin Hthalassemia disease. Blood 13: 492-501.

41. Bianco, I. \& M. Muzzolini. 1959. Clinical, hematological and genetic study of 4 new cases of $\mathrm{Hb} \mathrm{H}$ diseease with microcythemia. Progr. Med. (Naples) 15: $536-543$.

42. Koler, R. D. \& D. A. Rigas. 1961. Genetics of haemoglobin H. Ann. Human Genet. 25 : 95-100.

43. Lie-INJo, L. E., G. T. TJOA \& L. K. Kho. 1961. Splenectomy in a case of chronic haemolytic anaemia associated with haemoglobin $H$. J. Trop. Med. Hyg. 64: 136-139.

44. Sturgeon, P., R. T. Jones, W. R. Bergren \& W. A. Schroeder. 1962. Observations on "Bart's" and the "fast" hemoglobins of thalassemia-Hdisease. Proc. 8th Cong. Internat. Soc. Hemat., Tokyo. : 1041.

45. Bingle, J. P., E. R. Hughns \& T. A. J. Prankerd. 1958. Haemoglobin-H disease. Brit. Med. J. 2: 1389-1390.

46. NeEL, J. V. 1947. The clinical detection of the genetic carriers of inherited disease. Medicine 26: 115-153.

47. De Traverse, P. M., C. Le Xuan \& M. L: Coquelet. 1960. Les hémoglobinopathies au Viet-Nam. Proc. 7th Cong. Europ. Soc. Haemat. London, (Part II) : 1053-1057.

48. Tuchinda, S., D. L. Rucknagel, V. Minnich, U. Boonyaprakob, K. Balankura \& V. Suvatee. 1962. Hemoglobin E suppression by thalassemia in Thais. Presented at the 9th Cong. Internat. Soc. Hemat. Mexico City, Mexico.

49. Cohen, F., W. W. Zuelzer, J. V. Neel \& A. R. Robinson. 1959. Multiple inherited erythrocyte abnormalities in an American Negro family: hereditary spherocytosis, sickling and thalassemia. Blood 14: 816-827.

50. Shepard, M., D. J. Weatherall \& C. L. Conley. 1962. Semiquantitative estimation of the distribution of fetal hemoglobin in red cell populations. Bull. Johns Hopkins Hosp. 110 : 293-310.

51. LiE-INJo, L. E. 1962. Alpha-chain thalassemia and hydrops fetalis in Malaya: report of five cases. Blood 20: 581-590.

52. JACOB, F. \& J. MoNOD. 1961. Genetic regulatory mechanisms in the synthesis of proteins. J. Mol. Biol. 3: 318-356. 
53. Wheeler, J. T. \& J. R. Krevans. 1961. The homozygous state of per'sistent fetal hemoglobin and the interaction of persistent fetal hemoglobin with thalassemia. Bull. Johns Hopkins Hosp. 109: 217-233.

54. MotUlsky, A. G. 1962. Controller genes in synthesis of human haemoglobin. Nature (London) $194: 607-609$.

55. Itano, H. A., 1957. The human hemoglobins: their properties and genetic control. Advan. Protein Chem. 12: 215-268.

56. Jones, O. W. \& M. W. Nirenberg. 1962. Qualitative survey of RNA codewords. Proc. Nat. Acad. Sci. U. S. 48: 2115-2123.

57. NANCE, W. E. 1963. Genetic control of hemoglobin synthesis. Science 141 : $123-130$. 